\title{
THE INTERACTIONAL APPROACH TO THE TEACH- ING OF WRITING AND ITS IMPLICATIONS FOR SECOND LANGUAGE ACQUISITION
}

\author{
Lies Amin Lestari \\ Universitas Negeri Surabaya, Surabaya
}

\begin{abstract}
Writing is a language skill which is relatively difficult to acquire. A number of efforts have been made to develop the students' writing skill, among others is by applying different approaches to the teaching of writing. This article discusses the interactional approach to the teaching of writing and its implications for second language acquisition.
\end{abstract}

Key words: interactional, approach, writing, SLA.

As one of the four language skills, writing has traditionally occupied a place in most English syllabuses. Even so, arguments are sometimes put forward for not teaching students to write because it is felt that a command of the spoken language and of reading is more important. For many students this may be true, but today, given the importance of English as an international language, more and more people need to learn to write in English for occupational or academic purposes. Because of the reasons above, instead of being the last skill to teach, writing has now become a much more important subject to be taught in second/foreign language curriculum (Leki, 1994).

In an EFL classroom, students must develop communicative writing competence in the new language and learn the rhetorical structure, which will probably be quite different from the rhetorical structure of their native language (He, 1989). That is why teacher should help the students develop a different attitude towards writing by encouraging them to concentrate on thinking of con- 
tents and on expressing their thought clearly, rather than concentrating on avoiding mistakes (Lopes, 1991). Since writing is basically a form of communication, it is therefore essential to make the teaching of writing as communicative as possible (Liu, 1991).

The stereotype pattern of teaching writing is the teacher gives a topic and the students write a paper on it. During the class hour, the students are left to wrestle as best as they can with the mysterious process of composing. When they are finished, the teacher then reads, corrects, and grades the papers. The teacher is often too demanding about grammatical correctness and focuses the assignment primarily on language structure (Leki, 1994). She pays detailed attention to mistakes in language forms as she thinks that mastery of forms is an important and prerequisite for writing. Students get good grades if they write texts with as few errors as possible. To avoid errors, then, students naturally write very cautiously and conservatively in the second language. The result could be students' writing that is crippled, filled with clichés, and very boring for both the teacher and the students who write it.

The above traditional approach to teaching writing is deficient in three important respects. First, the teacher views the students' writing as a product. She assumes that the students know how to write and use what the students produce as a test of that ability (Hobelman and Wiriyachitra, 1989). Second, the teacher focuses on form, i.e., syntax, grammar, mechanics, and organization, rather than on content (Hobelman and Wiriyachitra, 1989). Third, the teacher also frequently complains that the students' writing is uncreative and poorly organized (Lopes, 1991). Such a style in teaching, although not without its virtues, tends to be de-motivating because the students tend to work "passively" from the beginning to the end and, on top of it, they receive only marks (He, 1989). If the writing classroom is always conducted that way, it will be possible that the writing classroom can become a source of frustration for both the students and the teacher. The students will become confused and distressed with the demands of their writing assignments, and the teacher will get frustrated as the students' compositions do not meet her expectation.

A good teacher will always try to do the best to allow her students to learn as much as they can. To overcome the problems and to help the students produce readable English passages, the students should have a great amount of writing practice. In order to guarantee that the students write abundantly, the teacher should not worry about the grammatical or mechanical mistakes in their paper too much $(\mathrm{He}, 1989)$. The teacher must remember that readers of student 
writing, with the exception of English language teachers, do not look for perfect grammar but for sound arguments and accuracy of message (Chandrasegaran, 1989). In addition, a number of efforts, including trying out a variety of teaching approaches that will help the students learn to write, should be attempted. One of the approaches that is worth trying is the so called interactional approach.

\section{THE INTERACTIONAL APPROACH TO THE TEACHING OF WRIT- ING}

The interactional approach to the teaching of writing is based not only on the needs of language students as perceived by the teacher and textbook writers, but also on insights from second language acquisition theory and research. In an interactional approach, emphasis is placed on meeting students' needs both in gaining control over the conventions of written English and in obtaining opportunities for self-expression. Thus, the key components include provision of written input and feedback to students' writing and the use of the students' own work as a starting point for stimulating hypothesis about target language rhetorical and grammatical structures (Pica, 1986).

When employing the interactional approach, the teacher allows the students to receive feedback from both the teacher and peers. Teacher's feedback provided to students in an interactional approach is different from the one given in other approaches (Pica, 1986). In an interactional approach, teacher's feedback is not in phrase-level comments or oral comments or in the form of graphic devices, such as underlining, circles, arrows, etc., but in paragraphlevel written comments. In the more traditional approaches-the models, process, and integrated approaches-comments on students' writing are usually in the form of short written comments or oral comments or graphic devices which tend to limit the written input that can serve as meaningful intake relevant to the writing skills the teacher is seeking to develop in the students. This makes the teacher and the students become unequal partners in written interaction.

Related to the types of feedback given to the students, research done by Robb, et al. (1986) found that detailed feedback on sentence level mechanics may not be worth the instructor's time and efforts. That is why, it is suggested that teacher respond to students writing with comments that force the students back to the initial stage of composing, to the point where they are shaping and 
restructuring their meaning. It is believed that students who negotiate meaning in conferences with a teacher are more likely to be accurate in their use of the language than those whose attention is constantly drawn to surface-level inaccuracies and repair techniques (Sheppard, 1992).

In a writing class implementing the interactional approach, students are allowed to receive feedback from their peers and teacher during the process of writing. The feedback can be given to any aspects of composition, such as, content, organization, or language. Feedback on such aspects would enable the student writers to write better. Research by Fathman and Whalley (1990) found that "there was almost no difference between content scores on rewrites ... when only content feedback was given as opposed to when grammar and content feedback were given at the same time." Lipp (in Lipp and Davis-Ockey, 1997) found that $90 \%$ of her intermediate level students, who received a concentration of content comments along with some grammar comments, earned higher content scores on their rewrites. These studies suggest that between drafts, the comments can emphasize content while including some grammar feedback. Ellis (1994) notes that the teacher's use of referential or open questions may result in more negotiation and more complex learner output. Improvement on the students' writing is possible since in the interactional approach, the input that the students receive is directed specifically to them in the form of teachers' feedback about their own work. This kind of input is likely to be more comprehensible than other sources of input to which they are exposed, for example, textbooks.

There are three reasons why student writers need feedback for their writing (Raimes, 1985). First, being unskilled writers, students take less time to plan and their plans are less flexible than those of the good writers. Second, they rescan large segments of their work less often. When they do rescan it, it is usually more for the purpose of surface error correction than for assessing the fit between their plan and their product. That is why, their revision is mostly editing: the changes they make focus on form rather than on content as they are overly and prematurely concerned with accuracy. Finally, once they put ideas on the page, they seldom rework those ideas in the first draft to produce the final draft, or if they do the rewrite, the new one resembles the previous one. Those factors make unskilled writers unable to revise their work efficiently as they only focus on local concerns in their texts. If ESL students are given enough time, shown enough ways to explore topic, and given enough feedback, they will discover and uncover the English words they need as they 
write. With context, preparation, feedback, and opportunity for revision, students at any level of proficiency can be engaged in discovery of meaning.

Most students want to have every error marked by the teacher to enable them to correct their errors themselves (Leki, 1994). When employing the interactional approach, however, it is suggested that teacher allow the students to receive feedback not only from the teacher but also from the peers. Calls for the use of peer feedback may become more common for two reasons (Jacobs, 1989). The first reason is the growing popularity of teaching writing as a process with several dimensions has made peer feedback more appropriate because there is more emphasis on revision. The other reason is these dimensions of the writing process - creating ideas, shaping those ideas into a piece of writing, and then fixing the form of that writing - provide more points at which feedback can be offered.

The reason why peers should also be invited to give feedback to the students' writing is because the roles and functions of teacher evaluation differs from those of peers' (Devenney, 1989). First, peers, unlike teacher, do not use grammar as a basis for evaluating writing. Teacher makes proportionally more comments than students. But the two groups do not apparently differ with regard to the kind of comments made about writing style. Second, both teacher and peers respond to the specific ideas and information presented in the students' compositions; and they use these responses about content to make evaluative judgments about the papers. However, in the category of writing style students make proportionately more evaluative comments than teacher does. The peers are intent on trying to form text by informing it. They understand and point out that the peers' writing could be made better because students in collaborative tasks 'notice' the gap between what they want to say and what they can express and work together to solve their linguistic difficulties (Roskams, 1989). This analysis does not mean to imply that teachers do not make evaluative comments to help students revise their text. However, there is a greater tendency for teachers to respond to a paper as a 'finished' piece of writing; whereas students respond to papers as 'works in progress.' Finally, analysis of the written evaluative responses shows that there is a valuable role for L2 student audiences. This role is related to peers' ability to illustrate a dynamic, interactive view of meaning and peers' tendency to see writing as unfinished text.

Research done by Sheppard (1992) found those who were constantly asked to search their repertoire for more communicative formulations-to con- 
stantly evaluate their writing and make its meaning clear-learn more about sentence length than those who were exposed to constant error-oriented feedback. L2 peer audiences serve an extremely important function. This makes the very diversity of peer responses different from those a single instructor. In terms of text organization, Sheppard (1992) also found that L2 teachers and peers did not display sharply contrasting views about organization in writing. The greatest number of teacher comments and the second greatest number of peer comments concerned organization. ESL teachers and students applied this criterion to all papers and they used organization-related comments to justify both favorable and unfavorable evaluation. Therefore, L2 peers and teachers should not be viewed as clearly distinct groups with fixed and opposing views of writing and evaluation.

Perhaps the key advantage put forward in support of peer feedback is that it changes students' role in the class (Jacobs, 1989). With an exclusive teacher fronted approach to writing instruction, the students' role limited to producing writing which will be read and evaluated solely by the teacher. In contrast, peer feedback broadens learners' involvement by giving them additional roles of readers and advisors. Hopefully, this addition to roles increases learners' insight into the writing process. A related benefit proposed for peer work is that it helps learners become more autonomous, thus preparing them to write without a teacher to correct their errors. A study by Roskams (1989) on Chinese EFL students' attitudes to feedback and peer assessment in an extended pair work setting found that students enjoyed pair work and proposed changing partners to get different inputs. Even though at the beginning most students preferred teacher's feedback, it lessened slightly at the end.

It is undeniable that the student writers may give inappropriate comments on their peer's writing. That is why when employing the interactional approach the teacher should also give input to the students' writing. In this way, if it happens that the peer's comments are inappropriate, the teacher could help the students improve the writing by providing suitable input. By so doing, the implementation of the interactional approach to the teaching of writing will also help student writers see writing as a non-linear process. Instead, they will see writing as a recursive process in which a writer edits and revises his work with the help of others before he presents his final work to his readers as what is experienced by a writer in a real world. 


\section{INTERACTIVE ACTIVITIES IN A WRITING CLASS}

Interaction is collaborative exchange of thoughts, feelings, or ideas between two or more people, resulting in a reciprocal effect on each other. In an interaction negotiation which requires attentiveness and involvement which are important for successful communication happens. Theories of communicative competence emphasize the importance of interaction as human beings use language in various contexts to negotiate meaning, or simply stated, to get an idea out of one person's head into the head of another person and vice versa (Gass and Selinker, 1993)

Based on the above description, it can be concluded that providing students with sufficient opportunity to interact with one another is important. Classroom interaction is not only possible for speaking class but also for writing class. In the theory of second language acquisition, it is believed that the more frequently the interactions occur, the more input the learners are exposed to. As a result, they will acquire better results. In a writing class, interaction is expected to help the students achieve better writing performance since interactive experiences could accelerate the process of acquiring writing (Pica, 1986; Simpson, 1998; and Fathman and Whalley, 1990).

In classroom settings, interaction can be in the form of student-student and student-teacher interactions. Student-student interaction is believed to be more conducive and gives more chance for the students to practice the target language. They are more involved in participation and interaction in pair or group work. As far as communicative L2 development is concerned, group work seems to be the most applicable in EFL classes in which the main objective of the instruction is the development of communicative competence (Huda, 1987). The main reason is that, in group work in which only a limited number of students are involved, individual student has more opportunities to learn to use the target language. Gaies (1983) mentions that this pattern of interaction has pedagogic and socio-affective advantages. The pedagogic advantage is that student-student interaction can increase students' self-reliance, confidence, and participation in communication. In terms of the socio-affective advantage, this type of interaction can increase motivation, strengthen mutual understanding, and decrease inhibition. This kind of interaction provides more productive input in the process of language learning.

As far as writing instruction is concerned, student- student interaction can be in the form of small group writing in which a group of students produce a 
piece of writing. The writing produced is thus called a joint product. Another possibility for small group writing is the members of the group share ideas and exchange information on a certain topic. After that, each individual student produces a piece of writing based on the idea and information discussed in the group. Peer-editing is another type of student-student interaction in a writing class. It is quite useful to have students to comment on another student's writing as usually people are quite critical to other's work. This can be done by asking the students to exchange their works and each of them comments and edits on the paper so that the writer has the opportunity to revise his/her writing. By responding to each other's writing, students can learn a lot. Such response provides the students with meaningful and relevant interaction, especially when the teacher helps them by providing guidelines for evaluation (Chen, 1988).

Another interaction pattern is the student-teacher interaction which is very common in language classroom setting. Teacher controls the students' activities by expressing something, instructing the students to perform activities, asking questions, etc. The students are then required to give responses or to do the activities given by the teacher. Teacher-student interaction offers at least two advantages (Chaudron, 1988). First, through this kind of interaction, the students can practice patterns of the target language and try to get meaning. Second, this interaction may give the students opportunities to use the learned grammatical points for production.

In relation to feedback for writing class, Brown (2001) suggests that feedback be provided throughout the composing process because based on the feedback given the students attempt to bring their expression closer and closer to the intended meaning. Feedback can be both from the instructor and peers. In addition, individual conferences between teacher and student should also be encouraged during the process of composing as these will help the students modify their interlanguage (IL) sentences produced in writing for greater message comprehensibility. The assumption is that this process of modification contributes to second language acquisition as opportunities for comprehensible input and output are equally important in language learning (Shehadeh, 1999).

A teacher can work with the students to develop the written work through one-to-one conferences. Teacher and students often point out the value of such conferences, especially when the teacher and student focus on specific aspects of the student's writing and the student has chances to negotiate meaning. Goldstein and Conrad (in Gebhard, 1996) found that students who are actively 
involved in the negotiation of their intended meaning in their compositions make revisions that results in improvements in their revised drafts.

\section{HYPOTHESES IN SECOND LANGUAGE ACQUISITION THEORY}

In relation to Second Language Acquisition (SLA) theory, Krashen and Terrel (1983) propose some hypotheses, among others are the input hypothesis and the monitor hypothesis. Other hypotheses concerning the SLA are the output hypothesis, proposed by Swain (in Izumi and Bigelow, 2000) and the noticing hypothesis, proposed by Schmidt (in Izumi and Bigelow, 2000). The input hypothesis says that in order for acquirers to move from a stage $i$ (where $i$ is the acquirer's level of competence) to a stage $i+1$ (where $i+1$ is the stage immediately following $i$ along some natural order) by understanding language containing $i+1$ (Krashen and Terrel, 1982). The input hypothesis claims that meaning is used to help acquire language (Krashen and Terrel, 1983). The monitor hypothesis states that conscious learning has an extremely limited function in second language performance; it can only be used as a monitor or an editor. The hypothesis says that when one produces utterances in a second language, the utterances are initiated by the acquired system, and his conscious learning comes into play later. Monitor is thus used to make changes after the utterances have been generated by the acquired system. This may happen before or after one speaks or writes (Krashen and Terrel, 1983).

The output hypothesis claims that under some circumstances output stimulates language acquisition by forcing the learner to process language syntactically. According to this hypothesis, whereas the learner can often comprehend a message without much syntactic analysis of the input, production forces the learner to pay attention to the forms with which intended messages are expressed. In this process, output is hypothesized to promote language acquisition by making learners recognize problems in their IL and prompting learners to do something about those problems (Izumi and Bigelow, 2000). The noticing hypothesis claims that noticing is necessary and sufficient condition for the conversion of input to intake for learning (Schmidt, in Izumi and Bigelow, 2000). Noticing, according to Schmidt, requires focal attention and awareness on the part of the learner. The noticing hypothesis further claims that what must be attended to and noticed is not just the input in a global sense but also whatever features of the input are relevant for the target system. Thus, attending to and 
noticing specific aspect of the input are considered to be of the primary importance in learning those aspects.

Swain (in Izumi and Bigelow, 2000) says that '.. in producing the target language, learners may notice a gap between what they want to say and what they can say, leading them to recognize what they do not know, or know only partially. In other words, under some circumstances, the activity of producing the target language may prompt second language learners to consciously recognize some of their linguistic problems; it may bring to their attention something they need to discover about their L2.' This function of output relates directly to Schmidt's noticing hypothesis which claims paramount importance for noticing in language learning (Izumi and Bigelow, 2000). According to this hypothesis, output facilitates the noticing problems in the IL and the relevant features in the input. This noticing may in turn stimulate the process of acquisition. In addition, if output really triggers attention to form, this attention is most likely to involve simultaneous attention to meaning, provided that the learner initiates production with the intention of conveying content, for example in writing. Under the noticing hypothesis, when L2 learners encounter problems with the means to communicate their message, they notice the problems; subsequent input exposure would then help them notice the gap between their IL and the target language model.

An early view of the function of output was to generate more input for the learner, but it appears that there is more central role for output in acquisition. It allows learners to use what they know in a productive way; it allows for the productive use of language. Comprehensible input thus refers to the need for a learner to be 'pushed toward the delivery of message that is not only conveyed, but that is conveyed precisely, coherently, and appropriately (Swain, in Gass and Selinker, 1993). Output provides learners with a forum for several important language-learning function, i.e., testing hypotheses about the structures and meanings of the target language, receiving crucial feedback for verification of these hypotheses, developing automaticity in IL production, and forcing a shift from more lexical and semantic processing of the second language to a more syntactic ones.

Recently, several SLA researchers have systematically argued that the function of learner's production is not only to enhance fluency and indirectly generate more comprehensible input, but also to facilitate second language learning by providing learners with opportunities to produce comprehensible output (Long, in Shehadeh, 1999). Learners achieve this by modifying and ap- 
proximating their production towards successful use of the target language (Swain, 1985 in Shehadeh, 1999). In the process of modifying their interlanguage (IL) utterances or sentences for greater message comprehensibility, they undertake some restructuring that affects their access to their knowledge base. The assumption is that this process of modification contributes to second language acquisition. This is due to the fact that opportunities for comprehensible input and output are equally important in language learning.

Comprehensible input is important, but modification of the input itself seems not to offer much help in language acquisition and interlanguage development, for it gives a learner only limited language data. Modification of the structure of interaction, on the other hand, facilitates acquisition as well as interlanguage development for it does not only make input comprehensible, but also gives a language learner experience in the use of the target language. In an attempt to produce communicatively competent language learner, a review of current literature suggest the importance of interaction in L2 classes. Providing language learners with more opportunities to use the target language means giving them opportunities to use the target language and to communicate realistically. According to Taylor (1987) SLA depends upon the extent to which learners are exposed to and involved in genuine communication in the target language.

\section{IMPLICATION OF THE INTERACTIONAL APPROACH TO THE TEACHING OF WRITING ON SECOND LANGUAGE ACQUISITION}

As mentioned previously, the interactional approach to the teaching of writing allows learners to get feedback during the process of writing. In relation to the hypotheses mentioned above, i.e., the output, noticing, input, and monitor hypotheses, it can be said that the provision of feedback, both from peers and teacher, make the four hypotheses work simultaneously during the writing process so that better output, i.e., the learners' final drafts, will be achieved. In the process of producing a composition, the students taught using the interactional approach first produced their first drafts. The drafts are the students' output. During the peer feedback and student-teacher conference sessions, the output is then discussed for improvements. The discussion covers all aspects of writing which make the message misunderstood. It can be said that during the discussion what is being discussed is the students' output. During 
the discussion, the students will notice the gap between what they wanted to convey and what they conveyed. In this session, they get comprehensible input as the input is what they really need in order that they can convey their message properly and accurately.

Varonis and Gass (1985a) say that comprehensible input serves to establish affective bond among speakers which then may lead to more cooperative negotiation exchanges in which learners feel comfortable in asking for clarification as an attempt to make transmitted/received input comprehensible to them. Negotiated interaction is important not only because it provides learners with an opportunity to receive input, which they have made comprehensible through negotiation, but also because it provides learners with opportunities that enable them to modify their utterances or sentences so that the output is more comprehensible (Varonis and Gass, 1985b). In an interaction, the negotiation of meaning, which is important for the production of comprehensible output between interlocutors, is prevalent. It is through the negotiation of meaning that interlocutors work together to provide comprehensible input and produce comprehensible output (Shehadeh, 1999).

After the discussion, students are given time to produce the final draft. In this stage, what is called monitor works as according to Krashen and Terrel (1983) there are three requirements that must be satisfied in order to use the monitor successfully. First, the performer has to have enough time. Second, the performer has to be thinking about correctness, or be focused on form. Even when there is enough time, if the performer more concerns with what to say rather than with how to say it, the monitor will not work. Third, the performer has to know the rule.

\section{CONCLUSION}

The above description shows that the interactional approach to the teaching of writing can help students acquire writing skill, one of the language skills which is considered difficult to achieve. However, it should be acknowledged that some efforts need be done if teacher wants to implement this approach. First, guidelines on how to give feedback on writing should be made so that students know what aspects should be seen in their peers' writing. Second, teacher should train the students to work with the guidelines in order that they know what to do when they should give feedback to their peers' writing. Be- 
cause in the interactional approach longer time is needed to produce a piece of writing, it is then recommended that the teacher only requires the students to write few compositions during the course. It is believed that writing few compositions of better quality will be more satisfying for both teacher and students rather than producing a lot of compositions of low quality.

\section{REFERENCES}

Brown, H.D. 2001. Teaching by Principles: An Interactive Approach to Language Pedagogy $\left(2^{\text {nd }}\right.$ Ed). White Plains, NY: Addison Wesley Longman.

Chandrasegaran, A. 1989. A Process Approach to Teaching Composition: Idea Generation and Planning. Guidelines, 11 (1): 1-15.

Chaudron, C. 1988. Second Language Classroom Research on Teaching and Learning. Cambridge: Cambridge University Press.

Chen, E. S. 1988. Teaching Research Paper Writing in EST: Content, Language, and Communication. Forum, 26 (4): 19-23.

Devenney, R. 1989. How ESL Teachers and Peers Evaluate and Respond to Student Writing. RELC Journal, 20 (1): 77-90.

Ellis, R. 1994. The Study of Second Language Acquisition. New York: Oxford University Press.

Fathman, A. \& Whalley, E. 1990. Teacher Response to Student Writing: Focus on Form versus Content. In Kroll, B. (Ed.). Second Language Writing. New York: Cambridge University Press.

Gaies, S. 1983. Learner Feedback: An Exploratory Study in Its Role in the Second Language Classroom. In Seliger, H. and Long, M.H. (Eds.), Classroom Oriented Research (pp. 190-212). Rowley, Mass.: Newbury House.

Gass, S.M. and Selinker, L. 1993. Second Language Acquisition: An Introductory Course. Hillsdale, N.J.: Lawrence Erlbaum.

Gebhard, J.G. 1996. Teaching English as a Foreign or Second Language. Ann Arbor: The University of Michigan Press.

Huda, N. 1987. The Merits of Group Work in Foreign Language Teaching. A paper presented at a seminar on Language Teaching at IKIP Malang and Sanata Dharma Catholic University Jogyakarta. 
Hobelman P. \& Wiriyachitra, A. 1990. A Balanced Approach to the Teaching of Intermediate-Level Writing Skills to EFL Students. Forum 28, (4): 3739.

He, G. Q. 1989. Let the Student Write Actively. Forum, 27 (2): 36-37.

Izumi, S. and Bigelow, M. 2000. Does Output Promote Noticing and Second Language Acquisition? TESOL Quarterly, 34 (2): 239-278.

Jacobs, G. 1989. Miscorrection in Peer Feedback in Writing Class. RELC Journal, 20 (1): 68-76.

Krashen, S.D. 1982. Principle and Practice in Second Language Acquisition. Oxford: Pergamon Press.

Krashen, S.D. and Terrel, T.D. 1983. The Natural Approach: Language Acquisition in the Classroom. Englewood Cliffs, NJ: Regents/Prentice Hall.

Leki, I. 1994. Teaching Second Language Writing: Where We Seem to Be. In Karl, T. (Ed.), Teacher Development: Making the Right Moves (pp. 170178). Washington, D. C.: USIA.

Lipp, E. and Davis-Ockey, D. 1997. Praise-Question-Encourage: Guidelines for Writing Teacher Comments between Essay Drafts. Forum, 35 (1): 1215.

Liu, C. 1991. Helping Students Prepare Psychologically to Write in English. Forum, 29 (4): 32-34.

Lopes, D. 1991. From Reading to Writing Strategies. Forum, 29 (4): 42-44.

Pica, T. 1986. An Interactional Approach to the Teaching of Writing. Forum, 24 (3): 6-10.

Raimes, A. 1985. What Unskilled ESL Students Do as They Write: A Classroom Study of Composing. TESOL Quarterly, 19 (2): 229-238

Robb, T., Ross, S., and Shortreed, I. 1986. Salience of Feedback on Error and Its Effectiveness on EFL Writing Quality. TESOL Quarterly, 20 (1): 8393.

Roskams, T. 1989. Chinese EFLStudents' Attitudes to Feedback and Peer Assessment in an Extended Pairwork Setting. RELC Journal, 30 (1).

Shehadeh, A. Insight into Learner's Output. Forum, 37 (4): 2 - 5.

Sheppard, K. 1992. Two Feedback Types: Do They Make a Difference? RELC Journal, 23 (1): 103-110. 
Simpson, J. M. 1998. Research Writing in a Foreign Language. Forum, 36 (2): 34-37.

Taylor, B.P. 1987. Teaching ESL: Incorporating a Communicative, Student Centered Component. In Long, M.H. and Richards, J.C. (Eds), Methodology in TESOL (pp. 45-60). New York: Newbury House.

Varonis, E.M. and Gass, S.M. 1985a. Non-native -Native Conversations. Language in Society, 14 (2)

Varonis, E.M. and Gass, S.M. 1985b. Non-native/Non-native Conversations. Applied Linguistics, 6 (12): 71 - 90. 